Article

\title{
Spanish Photovoltaic Solar Energy: Institutional Change, Financial Effects, and the Business Sector
}

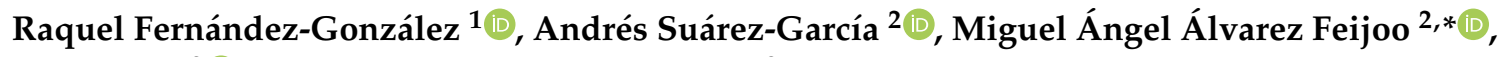 \\ Elena Arce ${ }^{2} \mathbb{D}$ and Montserrat Díez-Mediavilla ${ }^{3}$ \\ 1 ERENEA-ECOBAS, Department of Applied Economics and Faculty of Economics, Campus As \\ Lagoas-Marcosende, University of Vigo, 36310 Vigo, Spain; raquelf@uvigo.es \\ 2 Defense University Center at Spanish Naval Academy, 36920 Marin, Spain; asuarez@cud.uvigo.es (A.S.-G.); \\ elena.arce@cud.uvigo.es (E.A.) \\ 3 Solar and Wind Feasibility Technologies Research Group (SWIFT), Electromechanical Engineering \\ Department, University of Burgos, Avda. de Cantabria s/n, 09006 Burgos, Spain; mdmr@ubu.es \\ * Correspondence: alvarezfeijoo@cud.uvigo.es
}

Received: 7 February 2020; Accepted: 27 February 2020; Published: 2 March 2020

check for updates

\begin{abstract}
Spain is a country with a high dependence on fossil fuels. For this reason, in 2007, it implemented a bonus system that aimed to encourage the production of renewable energies, particularly photovoltaic solar energy. These production bonuses, guaranteed by the Spanish government, led to an exponential increase in the number of companies in the market and, consequently, the MWh produced. However, in 2012, given the excessive budgetary burden involved in maintaining this "feed-in tariff" system and after several years of institutional instability, the aforementioned system of incentives for phoyovoltaic (PV) energy was eliminated. This paper has tried to analyze the consequences of this institutional change, a clear example of the "hold up" problem. For this purpose, a sample of 5354 companies, which was divided, geographically, into Spanish regions and, temporarily, into three different periods, has been taken, considering diverse economic and financial variables. The results show a notable weakening of the sector that, due to the effects of the regulatory change, has lost attractiveness and profitability for investors and is consequently suffering from stagnation, which has led to the disappearance of many companies in the sector.
\end{abstract}

Keywords: Spain; solar photovoltaics; institutional frameworks for energy transition; hold-up problem

\section{Introduction}

The high dependence on fossil fuels in some countries causes a high energy bill. Among them is Spain, which imports large quantities of fuel oil [1-4]. In 2000, 74\% of the energy generated in Spain came from fossil fuels. By 2012, however, the share of fossil fuels had fallen considerably to $52 \%[5,6]$. This drop of more than twenty percentage points was the result of active policies implemented by the Spanish government. In order to follow European policies in terms of implementing a less polluting and more diversified energy model, Spanish governments promoted the production of renewable energies, focusing especially on photovoltaic solar energy $[7,8]$. In response to its concerns about energy efficiency and climate change, the European Union (EU) Directive 2009/28/EC was approved, which set the goal that $20 \%$ of the EU's energy consumption should be produced by renewable energies by 2020. This last decree shows how each member country takes into account the starting situation of the member countries and proposes different scenarios for each of them. Even so, the EU did not approve a common regulation for all its members, but rather it is they who decide how to promote it. 
Spain has very favorable climate conditions for a high production of solar photovoltaic energy, as it is one of the European countries with the highest number of hours of solar radiation. Figure 1 shows the map of climatic zones in Spain, including graphic indicators of daily insolation over horizontal surface. As can be seen in the figure, the regions in the southern half of the country have the greatest potential for harnessing this energy. For this reason, the government focused mainly on this type of renewable energy $[9,10]$. However, in addition, the decrease in the cost of solar panels made this technology one of the most attractive for investors, this being another reason that the government took into account $[11,12]$.

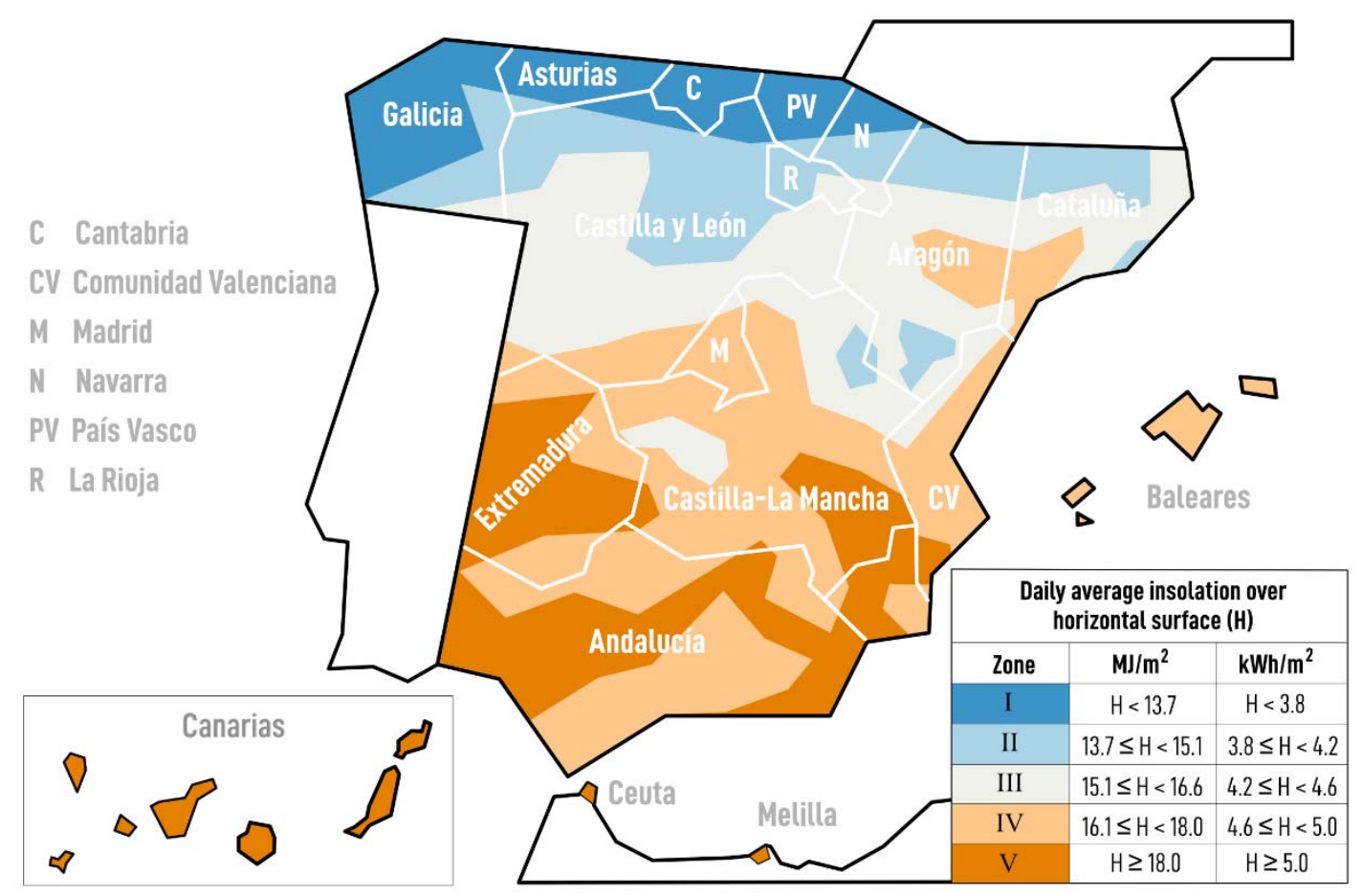

Figure 1. Map of climatic zones in Spain. Own elaboration with the data of [13].

As a result of this urgent need to reduce the energy bill and because of Spain's favorable conditions for obtaining cleaner and cheaper energy, since 2007, the government's energy decisions have focused on implementing a very aggressive subsidy policy, which has attracted thousands of investors and has led to the Spanish solar photovoltaic energy market experiencing great growth in the following years, both in terms of MWh produced and the number of companies in the sector (Figure 2). This is shown by the fact that in 2007, photovoltaic production was assumed to be $152 \mathrm{MWh}$, while in 2010 it reached $3842 \mathrm{MWh}$ and in 2018 the figure reached $4744 \mathrm{MWh}$ produced [14-16]. This policy had certain positive results: it increased the weight of renewable energies in the Spanish energy mix and reduced $\mathrm{CO}^{2}$ emissions (7,5 t CO2/capita in 2007; 5,6 t CO $2 /$ capita in 2010; 5,2 $\mathrm{t} \mathrm{CO}^{2} /$ capita in 2018) $[5,15]$.

These policies led Spain to achieve excellent results, with a notable decrease in fossil fuel consumption. In 2011, Spain reached the third place among the countries with more production in Europe, which, in that year, was the world region where more photovoltaic energy was produced.

However, despite these good results, the Spanish executive decided to make a change in policies to promote solar energy. The most important reason for this change was that the public treasury could not assume such a high cost overrun caused by the feed-in tariff system in a scenario of economic crisis. This renewable energy incentive system was widening the gap between generation costs and revenues collected through tariffs, increasing the "tariff deficit" [5]. Moreover, the policy of premiums implied an enormous transfer of public resources towards investors in photovoltaic energies, with evident discomfort from other agents in the energy market, such as the large electricity companies who claimed that the system in general was becoming more expensive due to such premiums. Therefore, in 
2012, after a succession of increasingly restrictive laws with public subsidies for photovoltaic energy, these incentives were definitively abolished.

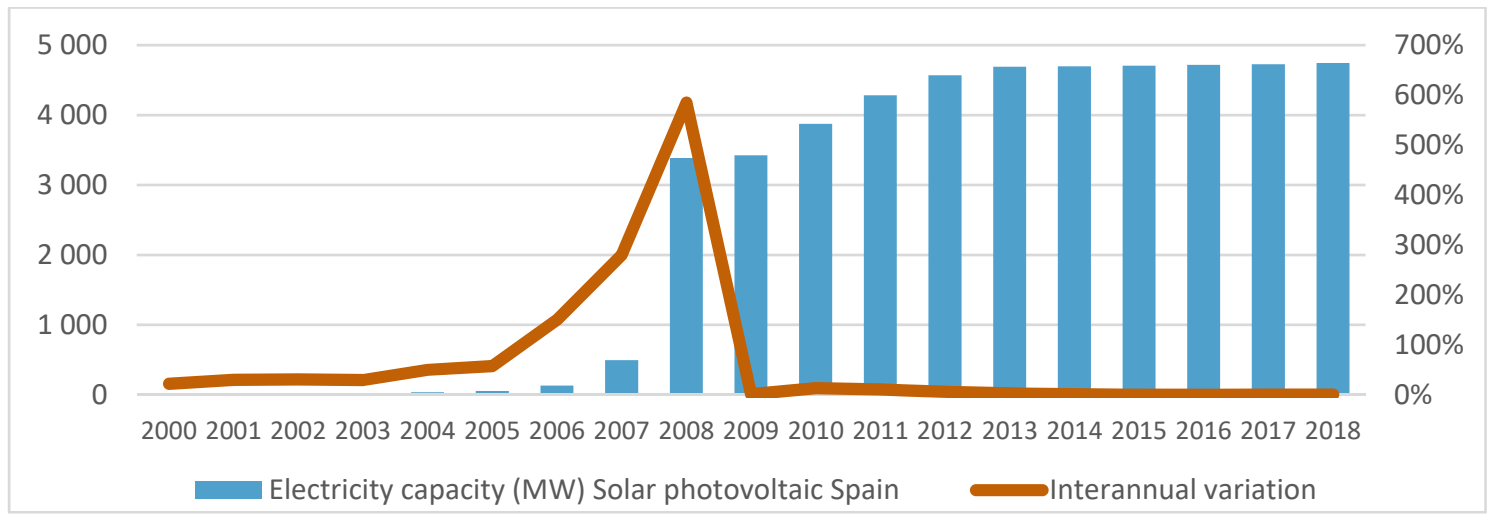

Figure 2. Photovoltaic solar power generated in Spain. Own elaboration with the data of [16].

The relationship between electricity companies and the country's political elites is an underlying factor that can be incorporated when explaining energy policy in Spain, although the study of these relationships for our case study is inconclusive due to the lack of qualitative information on the direct relationships between large companies and political leaders and the causality of decisions. In any case, it is true that even without the support of the electricity companies, the bonus policy was approved and applied by the government and was subsequently rectified by the same socialist government. Beyond the influence of lobbies on the executive's political agenda, it seems clear that the change in the economic scenario was the key factor. Thus, since 2010, the Spanish central government, faced with the doubts of the markets and the consequent pressure from the European institutions, was forced to implement a restrictive economic policy. This exemplifies the scenario of the change in government priorities. The government was forced to modify its policy on renewable energies, which had involved unexpectedly rapid expansion. The effects of the cancellation of the feed-in tariff system were very significant. Although PV solar power generation continued to grow, from 2014 onwards this growth slowed down enormously, with an annual growth rate between $0.15 \%$ and $0.40 \%$ between 2014 and 2018 [16]. This trend in production, together with the few companies that entered the market, leads to the stagnation of the sector. In fact, the direct consequences of institutional change have fallen on the business sector. This agent has seen how it has gone from a favourable economic scenario, where the profitability of investment in photovoltaics was high, to a completely unfavourable scenario as the regulations have changed. As a result of the change, the possibilities of return on the irreversible investments made are drastically reduced, to the point that neither minimum returns nor capital amortisation are guaranteed $[14,17,18]$.

The magnitude of the change in energy policy and its implications have been widely studied by academia. Although there is a wide variety of economic studies that have analyzed this case $[7,8,14,17-24]$, this paper provides a novel approach by combining the use of the New Institutional Economics (NIE) approach and the qualitative evidence derived from the processing of data from a longitudinal population sample of 5354 companies. This combination has allowed an analysis of the evolution of key economic-financial variables to understand how institutional change has affected the Spanish private energy sector. The paper is structured in five sections. The second section analyses the institutional change in the Spanish PV sector based on the New Institutional Economics (NIE) fundamentals. The third section explains the methodology used for the empirical study, which treats the data derived from the sample population of 5354 companies. The fourth section analyses the economic-financial results derived from the empirical study. Finally, the fifth section presents the conclusions of the paper. 


\section{Spanish Photovoltaic Sector}

The regulatory framework for renewable energies in Spain was developed in the 1980s through a law promoting mini-hydro (Law 82/1980 on energy conservation). This law was developed in order to address the oil crisis and improve energy efficiency. An important milestone in the regulation is set by Royal Decree (RD) 2818/1998 on the production of electricity by installations supplied by renewable energy resources or sources, waste, and cogeneration (repealed by Royal Decree 436/2004 and subsequently by RD 661/2007), which establishes that the premiums of the special regime should be updated annually and revised every 4 years. RD 661/2007 maintains sale at a regulated tariff (established in RD 436/2004), which is the fixed price that the producer receives for the energy dumped into the system, or directly into the market, receiving the price negotiated in the system plus a premium, with the total remuneration being cap and floor.

RD 1578/2008, which reviewed RD 661/2007, modifies the economic regime for the production of electricity using photovoltaic solar technology for installations after the deadline for maintaining remuneration under RD 661/2007. The remuneration of these installations is based on different annual calls with power quotas by typology and is adjusted to the learning curve of the technology (the price and power quota is specified for each call), which results in a lower cost of electricity in relation to the previous model. Additionally, this RD 1578/2008 limits the application of RD 661/2007. RD 222/2008 sets the annual updates of the tariffs and the upper and lower limits of the special system. Due to the economic impact that renewable energies have on the tariff system, RD Law 6/2009 was approved in order to establish mechanisms for the remuneration system for special regime installations (except for photovoltaic technology, which is already regulated in RD 1578/2008), and thus guarantee the sustainability of the system, both from a technical and economic point of view. The need to limit the accumulation of tariff deficits by the Spanish electricity system led to a reduction in incentives for the photovoltaic system, as reflected in RD 1565/2010. Figure 3 shows the evolution of the investment made in Spain [19].

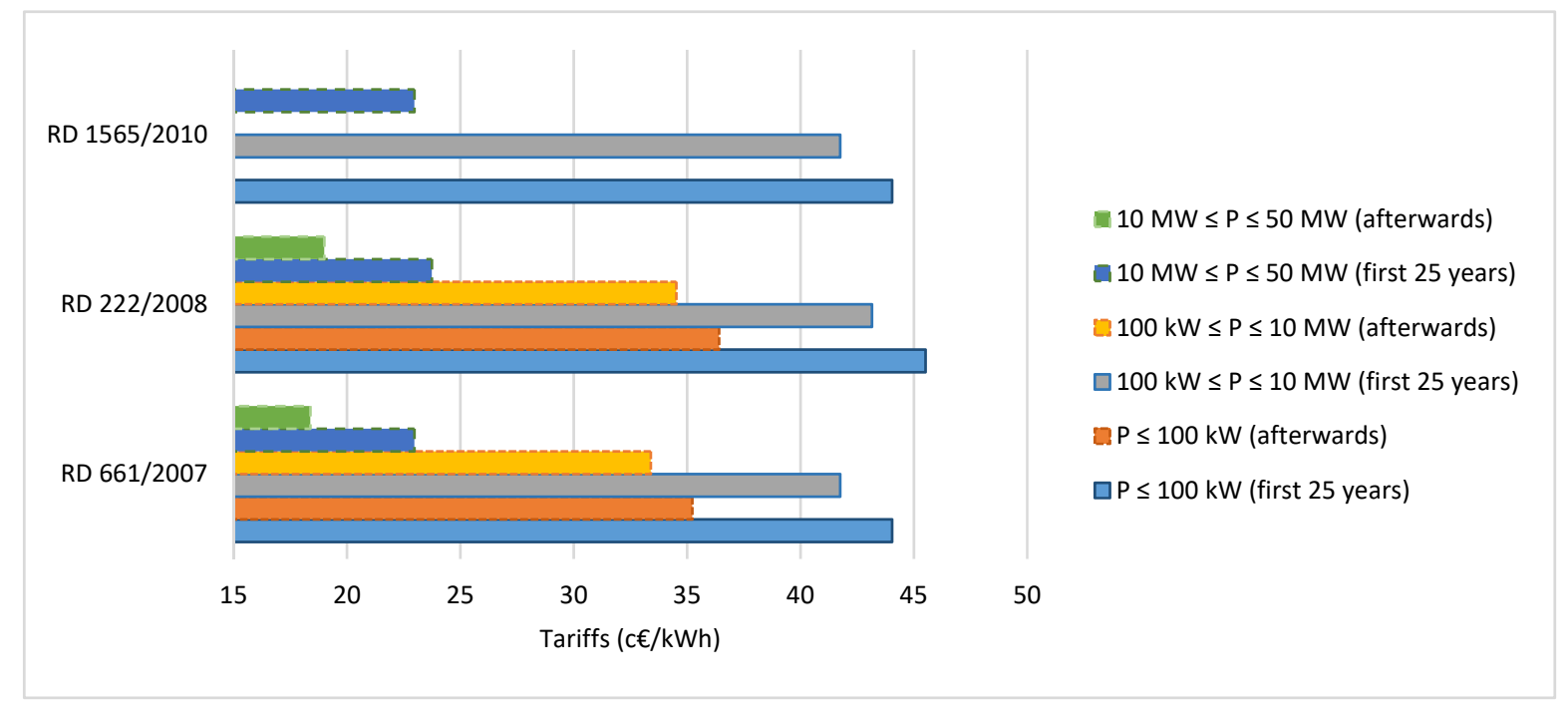

Figure 3. Tariffs in the Spanish photovoltaic (PV) regulatory framework. Own elaboration with the data of [19].

Figure 4 (top figure) shows how the installed power increased significantly in 2008, and moderately from 2008 to 2011, and between 2012 and 2016 it practically stagnated. In relation to the energy generated (Figure 4, average), due to the large number of new installations, in the period 2007-2011 the power generated shot up. Until 2012, when the change in policies will stagnate the generation. Additionally, Figure 4 (below) shows the ratio called Peak Sun Hours, which is an hour during which the intensity of sunlight is 1000 watts per square meter). Its meaning is the number of hours of sunshine 
at $1 \mathrm{~kW} / \mathrm{m}^{2}$ to obtain a given insolation. The figure stays around $1500 \mathrm{~h}$. There is a relationship with the map of Building Technical Code areas. The Building Technical Code in Spain is known as Código Técnico de la Edificación, CTE. If we transform the $\mathrm{kWh} / \mathrm{m}^{2} /$ day to $\mathrm{h}$ of the figure, its values oscillate between 1387 and $1825 \mathrm{~h}$. Therefore, the ratio obtained is an expected value [25].
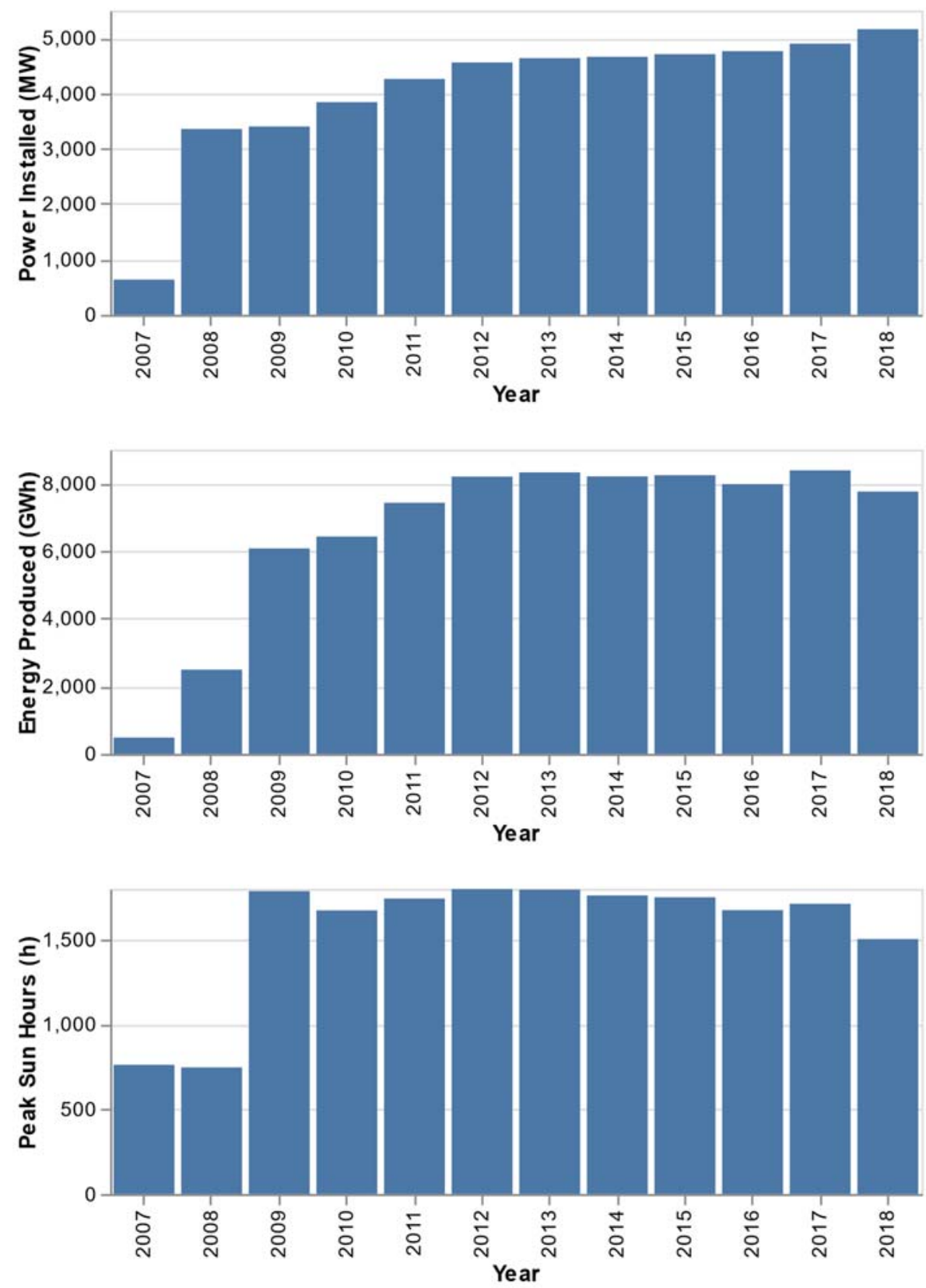

Figure 4. (Top) Power Installed, (Average) Energy Produced, and (Below) Peak Sun Hours in Spain. Own elaboration with data the of [25].

When analyzing the evolution of the installed power within the Spanish territory (by Autonomous Communities (CCAA)), it can be seen that Castilla-La Mancha is the region with the most solar photovoltaic power installed with almost $20 \%$ of all national power, followed closely by Andalusia and a little further away by Extremadura and Castilla y León [26]. These four communities represent the $61 \%$ of the installed photovoltaic power in Spain. (Figure 5), as they are in the southern half of the country where most radiation is received. Another factor to take into account is that in these regions the surface available for installations is high. Solar power output has stabilized over the past three years 
after a long path of continuous growth. Photovoltaics began to take off in 2000 with $1 \mathrm{GW}$ installed, reaching a record growth figure in 2008 with the installation of 2733 new MW of power, growth that continues until 2013 with more than 250 MW installed each year on average, to remain practically unchanged since then. In 2018, photovoltaics represented 3\% of total electricity generation [25]. In 2017, photovoltaic solar energy increased its contribution to the national GDP by $7.2 \%$, maintaining the upward trend that began in 2015 [27]. The reasons for the advance experienced by this technology are the activity associated with self-consumption and a greater investment by the companies for the implementation of the new projects awarded in the auction of July 2018, where there were more than $4000 \mathrm{MW}$ of new photovoltaic solar power to be installed before 2020. Despite the auctions that were carried out, the Spanish photovoltaic sector was still in crisis in 2018 as a result of the electricity reform of 2012 and the retroactive measures included in the RD Law 14/2010 and RD 413/2014.

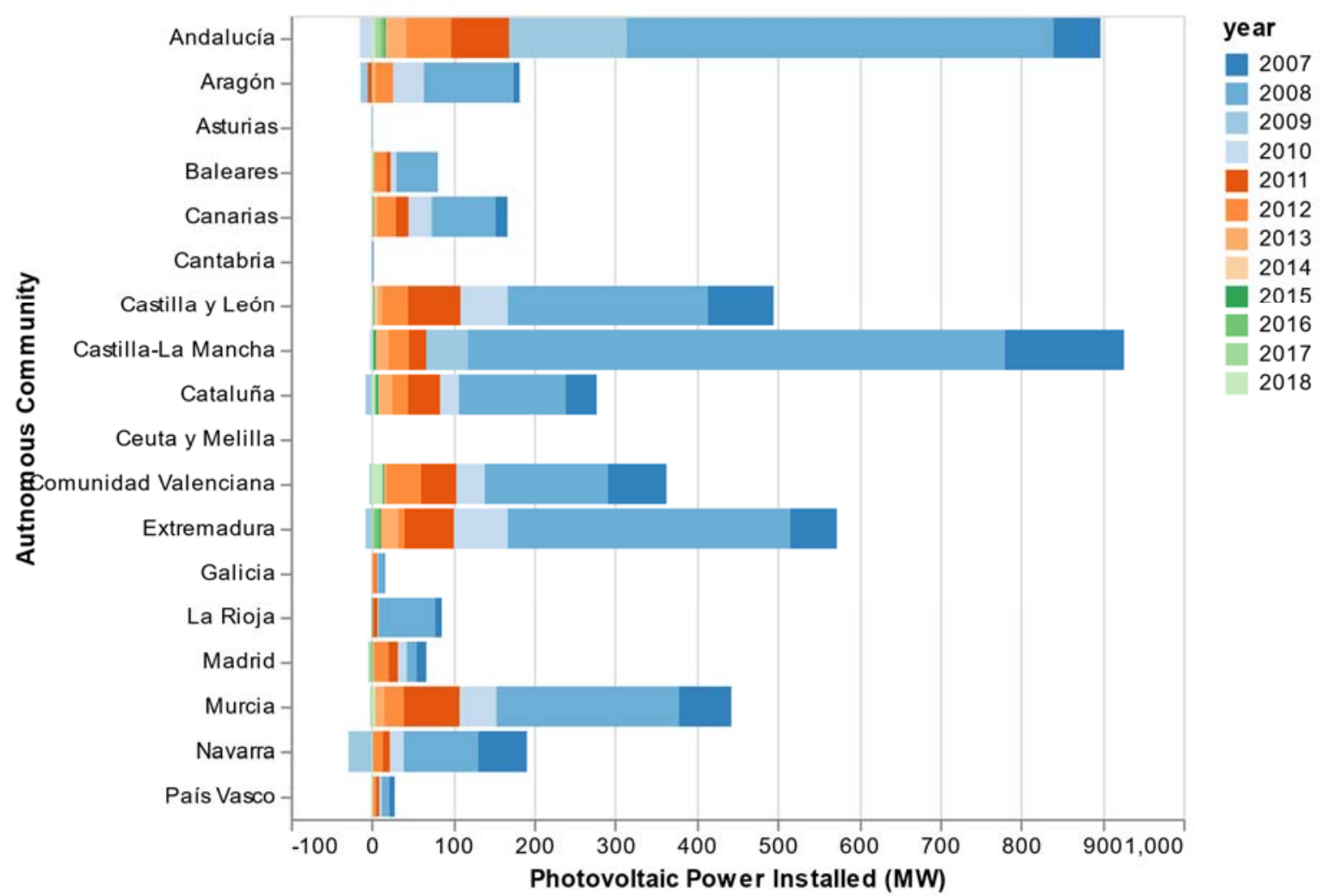

Figure 5. Evolution of Photovoltaic Power Installed in Spain by Autonomous Communities (CCAA). Own elaboration with the data of [26].

Until the new self-consumption registry defined in RD244/2019 is implemented, the only official reference regarding the territorial implementation of self-consumption in our country is the Administrative Registry of Self-consumption of Electrical Energy". This registry consists of two sections corresponding to the two types of self-consumption: without surplus (Section 1) and with surplus (Section 2). Additionally, the installations are classified into types. Therefore, within the T1.1 (Type 1 and Section 1), the installations of self-consumption mode "Type 1" with a contracted power lower or equal to $10 \mathrm{~kW}$ are framed. Within T1.2 (Type 1 and Section 2), "Type 1" self-consumption mode installations with a contracted power greater than $10 \mathrm{~kW}$ are framed, and within T2 (Type 2 and Section 2) the installations of Type 2 are framed. Figure 6 shows registered data of photovoltaic power for self-consumption installations until 31 December 2018. 


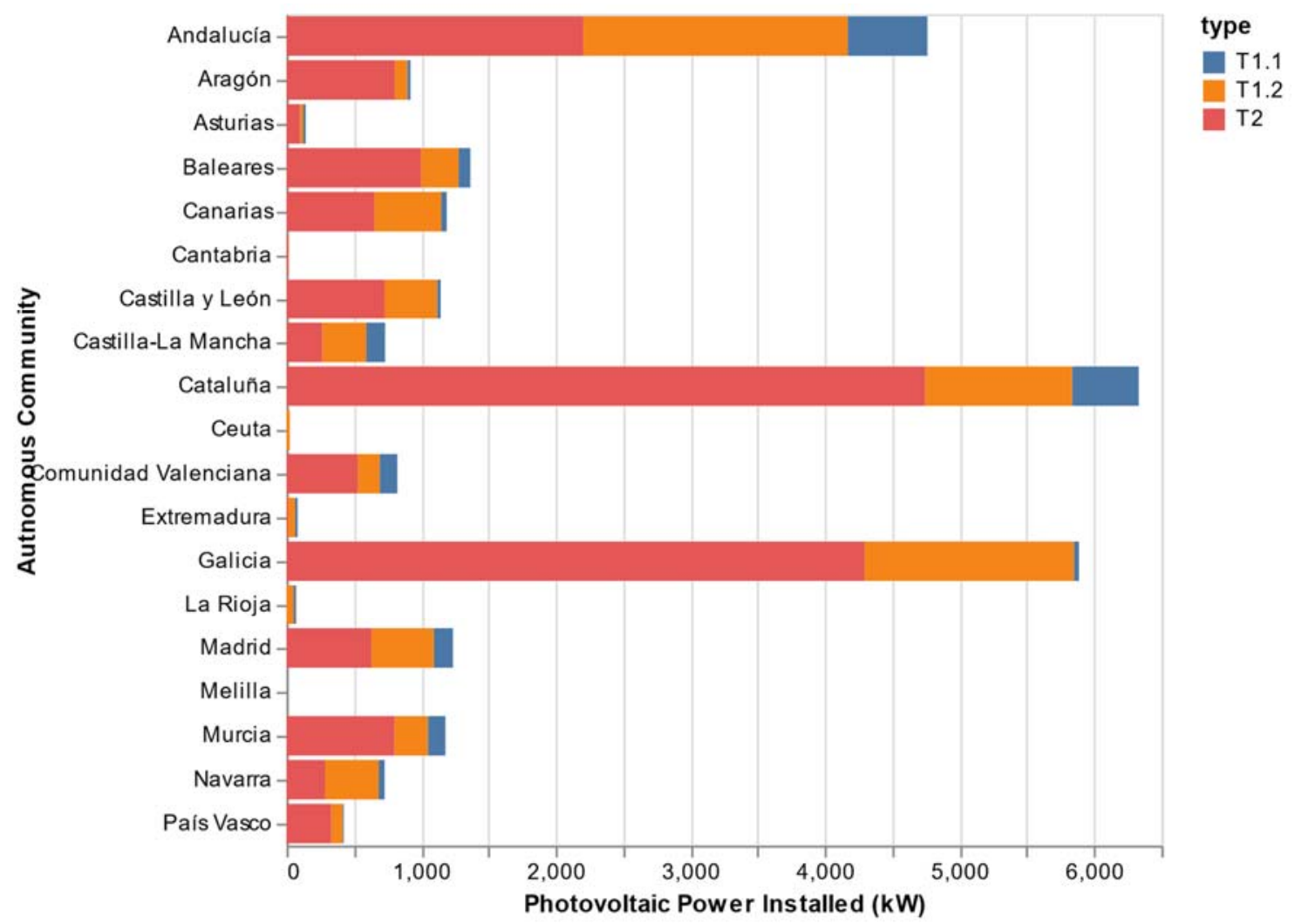

Figure 6. Installed photovoltaic power for self-consumption until 31 December 2018, by section, type, and region. Own elaboration with the data of [28].

The most notable aspect of these data is that the number of installations grew by $80 \%$ with respect to 2017. However, the increase in installed power was only $40 \%$, which clearly indicates that most of the installations commissioned in 2018 were small. The number of Type 1 installations with outputs up to $10 \mathrm{~kW}$ increased by $143 \%$ in 2018, the number of Type 1 installations with outputs above $10 \mathrm{~kW}$ increased by $58 \%$ and the number of Type 2 installations increased by only $30 \%$.

As regards the geographical distribution, the largest number of self-consumption photovoltaic installations are to be found in the autonomous communities of Catalonia, Andalusia, and Galicia, in that order. However, in each of them, one type and section prevails: in Andalusia and Catalonia, Type 1 installations corresponding to Section 1 stand out, while in Galicia, Type 1, Section 2 installations have a greater presence.

These three communities are also the ones that group together the greatest capacity for self-consumption in terms of power. Catalonia is in first position with $6.3 \mathrm{MW}$, followed by Galicia with $5.9 \mathrm{MW}$, and Andalusia with 4.8 MW. The three regions account for more than $62 \%$ of the installed power and $56 \%$ of the total number of installations [28].

The employment footprint groups all employment directly and indirectly associated and induced with the productive activity of the photovoltaic sector. In 2018, there was an increase in the number of direct and indirect jobs, which is expected to continue in 2019. Table 1 shows the evolution of the national or domestic direct employment footprint, that is, the workers directly employed in the different activities of the sector in Spain. This time series shows the effect of different regulations on the sector. Around $40 \%$ of the employment generated in Spain by the sector is due to the dragging effect of the Production activity and 25\% of the employment generated outside the Spanish borders [25]. 
Table 1. Direct and induced employment of the solar photovoltaic sector [28-30].

\begin{tabular}{ccccccccccccccc}
\hline Employment & $\mathbf{2 0 0 5}$ & $\mathbf{2 0 0 6}$ & $\mathbf{2 0 0 7}$ & $\mathbf{2 0 0 8}$ & $\mathbf{2 0 0 9}$ & $\mathbf{2 0 1 0}$ & $\mathbf{2 0 1 1}$ & $\mathbf{2 0 1 2}$ & $\mathbf{2 0 1 3}$ & $\mathbf{2 0 1 4}$ & $\mathbf{2 0 1 5}$ & $\mathbf{2 0 1 6}$ & $\mathbf{2 0 1 7}$ & $\mathbf{2 0 1 8}$ \\
\hline Direct & 5547 & 5778 & 6414 & 25,063 & 10,889 & 9952 & 10,013 & 9914 & 9302 & 8587 & 8818 & 8974 & 10,464 & 11,632 \\
\hline Indirect & 2932 & 2926 & 2911 & 2900 & 1615 & 1556 & 1670 & 1576 & 1446 & 1357 & 1392 & 1418 & 1845 & 2507 \\
\hline Total & 8479 & 8704 & 9325 & 27,963 & 12,504 & 11,508 & 11,683 & 11,490 & 10,748 & 9944 & 10,210 & 10,392 & 12,309 & 14,139 \\
\hline
\end{tabular}

This work has been oriented towards the impact that legislative changes have had on the financial and business sectors in Spain, in which the specific performance of the facilities has little influence. Although it is true that specific performance varies depending on the area, it is also true that it has not changed substantially, but the economic performance has managed to reduce the price of Wp by $85 \%$ (it has gone from 6 euros/Wp in 2006 to 0.8 euros/Wp in 2014). On the other hand, the upward trend of BIPV installations is the result of the imperative need to seek solutions to the energy problem, it is a priority to achieve buildings with zero consumption and self-sufficiency, in this field the PV plays a fundamental role, so there is a tendency to take advantage of solar energy in building. The problem outside Spain is incomparable since the legislation has suffered notable changes in Spain, while in the rest of the countries the energy policy has not varied so deeply, so the effect is not comparable [29-32].

\section{Institutional Framework of the Spanish Solar Photovoltaic Sector}

The New Institutional Economics (NIE) has established theoretical foundations that have allowed for significant advancement in the institutional analysis of resource management, including energy resources. The innovative nature of the NIE has led to the adoption of a multidisciplinary approach to the study of energy resources. Furthermore, it is important to point out that, in order to create a solid framework of study that is capable of providing solutions to the problems of the sector, case studies are an essential part, such as the one analysed in this paper. In a reality as complex as that presented by today's developed economies, the study of the various governance structures must be approached with tools that embrace complexity and incorporate it into the analysis. This is the case of the NIE. In this way, the NIE approach will help to draw solid conclusions adapted to the complexity demonstrated by the Spanish energy sector.

According to the New Institutional Economics, institutions are understood as the rules of the game of society [33] because they determine the structure of the economy, establish incentives for the economic behavior of agents and affect social interaction, and can promote or contract exchanges in an economy [34-36]. This happens, among other factors, because institutions redefine the level of uncertainty to which individuals are subject, stimulating or discouraging transactions by providing more or less certainty about what the actions of economic agents will be [37,38]. In this sense, it is important for an economy that the institutional structure reduces existing uncertainty and that regulatory stability is a fact, ensuring that institutional changes are balanced [39-41].

The process of institutional change described in this paper corresponds to the political action of the government and the legislative action of the parliament. Thus, although this work is eminently empirical, the theoretical framework for studying the problem is based on the New Institutional Economics. Under this research program we can study the transactional issues and governance structures of the third level of social analysis indicated by [42].

Before delving deeper into the institutional foundations, a brief description of the case is required. With the arrival of the economic crisis in Spain, and later, with the change of the government of the country in 2011, there was a brake in the energy policy that financially supported the installation of photovoltaic plants in plots of Spanish territory. In this case, the entrepreneurs who invested ex-ante in photovoltaic plants driven by the expected yields based on the high premiums offered by the government, see ex-post how the government changes policy, reduces the premiums, and eliminates the profitability of such investments already made, making it impossible for investors to recover what has already been invested. This change implied a massive reduction in the bonus attributed to entrepreneurs who produce solar energy in the "solar farms" [18,43]. 
The purpose of the study, in this case, is to analyze how the change of incentive policies to a sector reduces the return on investments in it, and how these investments once made cannot have any other purpose than the generation of photovoltaic energy, constituting a "hold-up" problem analogous to that defined for the transactional economic theory of the company [14]. Within the economy of transaction costs, "the hold-up problem" is defined as the risk derived from the change in the formal contractual rules, which would suppose an "expropriation" or "robbery" of the irreversible investment made by the company [44]. It is precisely in this last type of relationship that the case study in this chapter is situated. Incomplete contracts and the risk of "robbery" of irreversible investments is even greater in political or political-private relations [45], because, in the world of politics, contracts are particularly complex, incomplete, difficult to guarantee their execution, and affect multiple agents. It follows that legislators can pass laws at any given time but that those laws can be changed later by those same legislators or by others. The inter-temporal component of public policy is vital in policy making [46].

At the same time, it should be noted that, in the existing distributive game in the electricity sector, each decision by the State implies the existence of winners and losers, especially since this is a sector in which there is room for different types of regulations and the application of laws. Well, it is true that the large electricity companies criticized the policy of premiums for solar farms, highlighting their very high cost, and demanded the elimination of them. Even when the rectification of the premium policy began with the new measures adopted for the solar energy sector in 2010, the large electricity companies continued to call for further adjustments in the premiums for renewable energies in order to limit the tariff deficit.

The time evolution of the case study reflects that the Spanish government underestimated the cost of the incentives to the public treasury (at an aggregate level, the special regime in energy received public funds for an amount exceeding 6 billion euros, which is two billion more than initially estimated). Moreover, when the first major law on the feed-in tariff system was passed, Royal Decree 661/2007, the economic crisis was already a reality in Spain [47]. Moreover, in view of this macroeconomic scenario of losses, the same government that implemented such high remuneration for solar energy had to gradually eliminate the tariff system. The elimination of the incentive system in 2012 diminished the attractiveness of the sector for investors, slowing down the growth of the sector until now [14].

From a transactional perspective, the incentive policy of solar fields can be analyzed as a contract in which the state promises incentives and aid that guarantee a high return while investors make an investment. The problem arises because the contract is incomplete and does not cover all contingencies, and furthermore these political contracts are not enforceable against a third party, as the political analysis of transaction costs has highlighted. This is why, in this analysis, the time horizon is a very relevant factor [14,48]. Between 2007 and 2010, the regulations applied by the government encouraged investment in solar energy. But from 2010, expected returns on investment began to plummet as laws approving public incentives were repealed. Due to this chain of events, it has been considered relevant to carry out an empirical study to quantify the economic losses of companies in the sector, as will be done in the following sections.

\section{Methodology}

To carry out the empirical sectorial analysis, we have used the SABI (Iberian Balance Sheet Analysis System) database. This database, for Spain and Portugal, contains the annual accounts of the companies included in the Mercantile register in the Iberian Peninsula. SABI is the Spanish extension of the Bureau van Dijk's Amadeus database. In order to delimit the population sample, four criteria were followed:

- Country: Spain;

- Tax on commercial and professional activities (IAE (All codes): 1514-Sun water and other form of energy; 
- National Classification of Economic Activities (CNAE) 2009. (Primary codes only): 3519-Other types of electric power production;

- Trade description: the words "photovoltaic" or "solar".

- Once these filters had been applied, we obtained a sample of 5354 companies.

- To characterize the evolution of the sector we have supported our analysis in four main variables collected in the economic balances of the companies in SABIs such as:

- The number of photovoltaic companies by date of creation in each Spanish Regional government segmented by period.

- The mean of Sales for each Spanish Regional government segmented by period.

- The mean of Operating Margin for each Spanish Regional government segmented by period.

- The mean of Financial Result for each Spanish Regional government segmented by period.

- For this analysis, it is considered that it would be necessary to complete it with a variable related to the sector's workforce. However, this has not been possible due to the lack of data on the number of employees in each company, since, in the fiscal accounts provided by SABI, this variable did not have a large number of records.

\section{Results}

The results of the financial analysis carried out with the sample collected from SABI reflect a sector with a wide expansion in a short period of time 2005-2009 thanks to institutional incentives (Figure 3), stopping one year before the approval of the Royal Decree 1565/2010 where the first reductions in photovoltaic energy production bonuses appeared. In addition, as previously shown, photovoltaic solar energy production has experienced generalized growth at the stage of approval of photovoltaic premiums, with a generalized reduction, from 2010 onwards, for all the climatic zones in Spain with the cancellation of premiums. The behavior of this variable is a concrete but representative example of what has happened in the sector, as other variables in the sample follow this pattern.

During the stage in which the variables are studied, 2001-2016, the world market for photovoltaic energy presented strong variations. At the beginning of the 21st century, Europe was the leading region for photovoltaic energy. In fact, it had the first and second largest Solar PV electricity generation in the world in 2011: Germany with 19,599 GWh generated and Italy with 10,796 GWh generated [49]. However, since 2012 it has been observed that the demand for photovoltaic solar energy production, clearly focused on the European market in recent decades, was being diverted to countries such as China, Japan, or India. Europe was already a mature market. In 2016, the push from China, the United States, and Japan had relegated Europe to second place, with Asia being the continent with the highest production, more than $50 \%$ of the total [50]. Through the different variables we will be able to carry out a more detailed analysis of the consequences and the factors of the institutional change that has occurred since 2008. Figure 7 shows, by periods, the number of companies per year of creation classified by regions. In the period 2001-2006, the most influential law, which would mark the beginning of premiums in the photovoltaic sector, was Law 54/1997 [14,22]. It stipulated premiums for those plants under $10 \mathrm{MW}$. With this law, the photovoltaic energy sector was promoted as a growing market with guaranteed profitability, although not very high, by the public sector itself. In 2004, Royal Decree 436/2004 was approved, which aimed to unify the different existing regulations to achieve a reference rate. This law extended the premiums for photovoltaics to installations of up to $100 \mathrm{~kW}$, establishing a system of sections that would set the guidelines for the following pieces of legislation within the sector. This first period experienced a continuous but moderate growth, since the investment in the photovoltaic installations was still sensibly expensive and the premiums of these first pieces of legislation were not as attractive as they would be in the following ones [51]. 

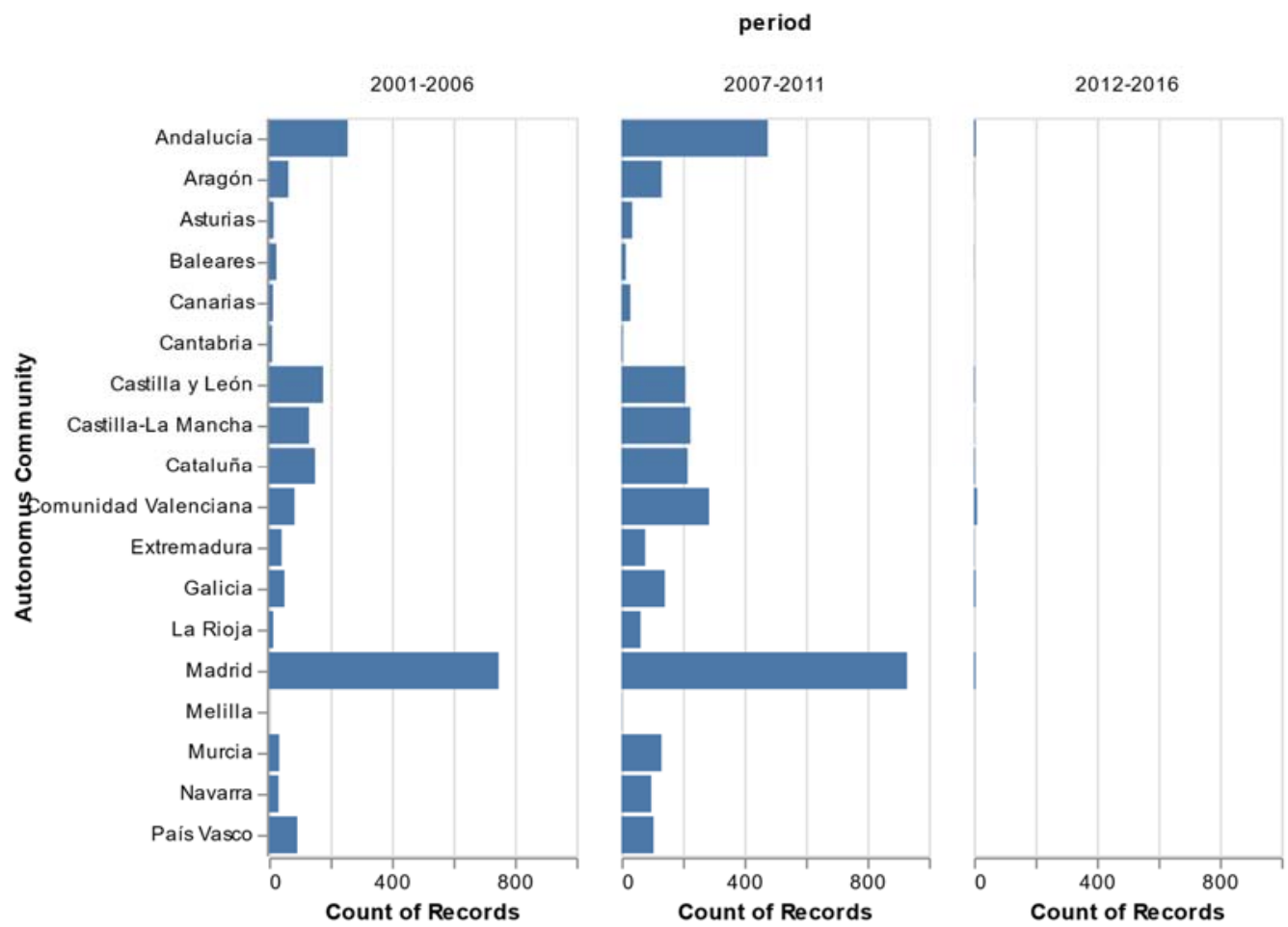

Figure 7. Photovoltaic companies count by the date of creation in each Spanish regional government segmented by period.

In the period 2007-2011, the great boom of the photovoltaic sector takes place. It is significant that before 2007 the photovoltaic power accumulated in Spain was 152 MW, while in 2010 it exceeded 3000 MW [20]. This exponential growth was marked by Royal Decree 661/2007, which established a fixed initial rate that would be updated with the level of inflation but also a maximum number of hours in which one could receive the incentives. Other contributions were as follows: a) the incentives would have a partial reduction at 25 years and b) the implementation of a ceiling of 371 MW of installed power in the Spanish territory where, once reached, the rates would be revised. The legislative framework implemented with this decree provided long-term stability and profitability, which attracted investment in this sector. However, in addition, there were other socio-economic factors that drove the great growth of photovoltaic energy [52]: (a) The global economic crisis affected Spain considerably. Sectors to which investment had traditionally been directed, such as construction, were no longer a safe business. Therefore, a business legally pursued by the public administration and with juicy premiums, such as solar energy, attracted the attention of investors. (b) The Spanish financial system, led by savings banks and banks, publicized this type of investment, making it reach different types of investors. Of the 20,000 million euros invested in this business, $75 \%$ of them came from national or foreign banks. (c) "Project finance" was created to facilitate the investment. Financial institutions founded them as micro-enterprises. These sought to pay the debt acquired for training with the returns on the investment, since the minimum profitability was guaranteed by law in the actual Decrees approved. (d) The characteristics of the solar modules favoured that they could be grouped in small photovoltaic parks and were more accessible to small investors, even individually. (e) The extra-official information about the hardening of the conditions for the installation of the photovoltaic panels after 2008 accelerated their installation with a date before this horizon. (f) The technology of the solar panels had improved and decreased in price and, consequently, energy production increased. In addition, the lower euro-dollar differential in 2006, 2007, and 2008 meant that imports were cheaper, which encouraged the purchase of photovoltaic panels. [23,52].

In Figure 7, we must pay attention to Madrid. We must clarify that in this figure the region of destination is attributed according to its fiscal domicile, not where the solar panels are located. Madrid, 
in addition to having better infrastructures that promote the industry, has a higher percentage of companies related to the photovoltaic sector but that are not direct energy producers. That is why, this region has a higher percentage of companies than other Spanish regions with more hours of sunlight per year $[14,49]$.

Until 2011, leaving aside the community of Madrid, a large number of companies were created related to this sector, in the regions with more hours of sunshine, highlighting Andalucia and Valencia. In the north of the country, the appearance of new companies was very small.

It is notable that the creation of new companies in the 2012-2016 period is much lower compared to previous periods. In fact, in that period, a considerable number of companies in the sector closed with the corresponding loss of jobs that this entails. This sharp interruption in the growth of the photovoltaic sector is intrinsically related to the institutional change that occurred in Spain since 2010. The prelude to the change in premium policies began with the approval of Royal Decree 1578/2008 [53]. This decree established a quarterly call procedure that established the price of $\mathrm{kWh}$. In this way, the Pre-Assignment of Retribution Registry (RPR) was created to control the installed power. Given the small quotas that were legislated and the delay in their allocation, a large number of projects were delayed in their implementation. However, the definitive change of rules occurred with Royal Decree 1003/2010, Royal Decree 1565/2010, and Royal Decree-Law 14/2010 [14,19]. With this new legal scenario, the owners of solar parks had to certify the date on which their plant began to operate, and according to this date, they would be entitled to charge one or another bonus. In addition, certain aspects of Royal Decree 661/2007 were revised, such as long-term bonuses, and technical innovations were required for the plants [18]. According to the calculations of the Spanish Government, these measures represented a saving of 740 million euros from 2011 to 2013. Consequently, the loss of profitability of some plants reached up to $40 \%$ [23].

In addition, the profitability of the sector worsened in 2013. When Royal Decree Law 2/2013 was approved, companies were forced to choose between the two existing mechanisms of retribution: go to the market or, in the case that the price does not cover generation costs, receive a compensatory bonus. However, the situation of the sector became critical when Royal Decree Law 9/2013 was approved, which completely eliminated the premiums for the generation of photovoltaic energy [22].

Another key variable when analysing the great growth of the photovoltaic sector in Spain is the amount of electrical energy produced under special regime sold (sales). Figure 8 shows a large increase in sales in the sector. From 2001 to 2008, the amount of sales tripled. In the later period, with an economic and institutional scenario not so favourable, sales stagnated.

To compare the affinity between the 2007-2011 and 2012-2016 periods, we must take into account that Royal Decree 661/2007 introduces the "floor and ceiling" system and, in the event that sales exceed the "ceiling" figure, it would only be perceived the roof support level (the roof level was reached at $100 \mathrm{Kw}$ ). That is why the variation of sales between the period 2007-2011 and 2012-2016 is minimal, since the photovoltaic plants, from its massive installation, decided to produce up to the limit "ceiling" and have maintained that level for the last two analysed periods [22]. As can be seen in Figure 8, the variation of the sales of the sector for the period 2007-2011 and 2012-2016 has been very small, even in aggregate terms it has decreased by several percentage points its aggregate variation rate for all of Spain [24]. This fact is due to the maintenance of the ceiling production figure (analysed above) and the brake on the creation of companies in the sector. Although the net change in the creation of companies has been positive in the 2012-2016 period, compared to the previous period, their figures are much lower.

Another variable analyzed is the operating margin (operating earnings/revenue), which obtained its worst results in the 2007-2011 period (Figure 9). The communities in the south and in the Canary Islands are among those that have suffered the least impact during these periods. The causes of its worrying development in this stage are due to the change in trend towards the photovoltaic sector of Spanish legislation. After the approval of Royal Decree 1565/2010, the sector reacted negatively to the change in rates and the negative outlook regarding its future. That is why the average operating profit 
decreased by five percentage points between 2009 and 2010. Following this trajectory, the inter-annual variation from 2012 to 2013 was minus 10 points [19,22].
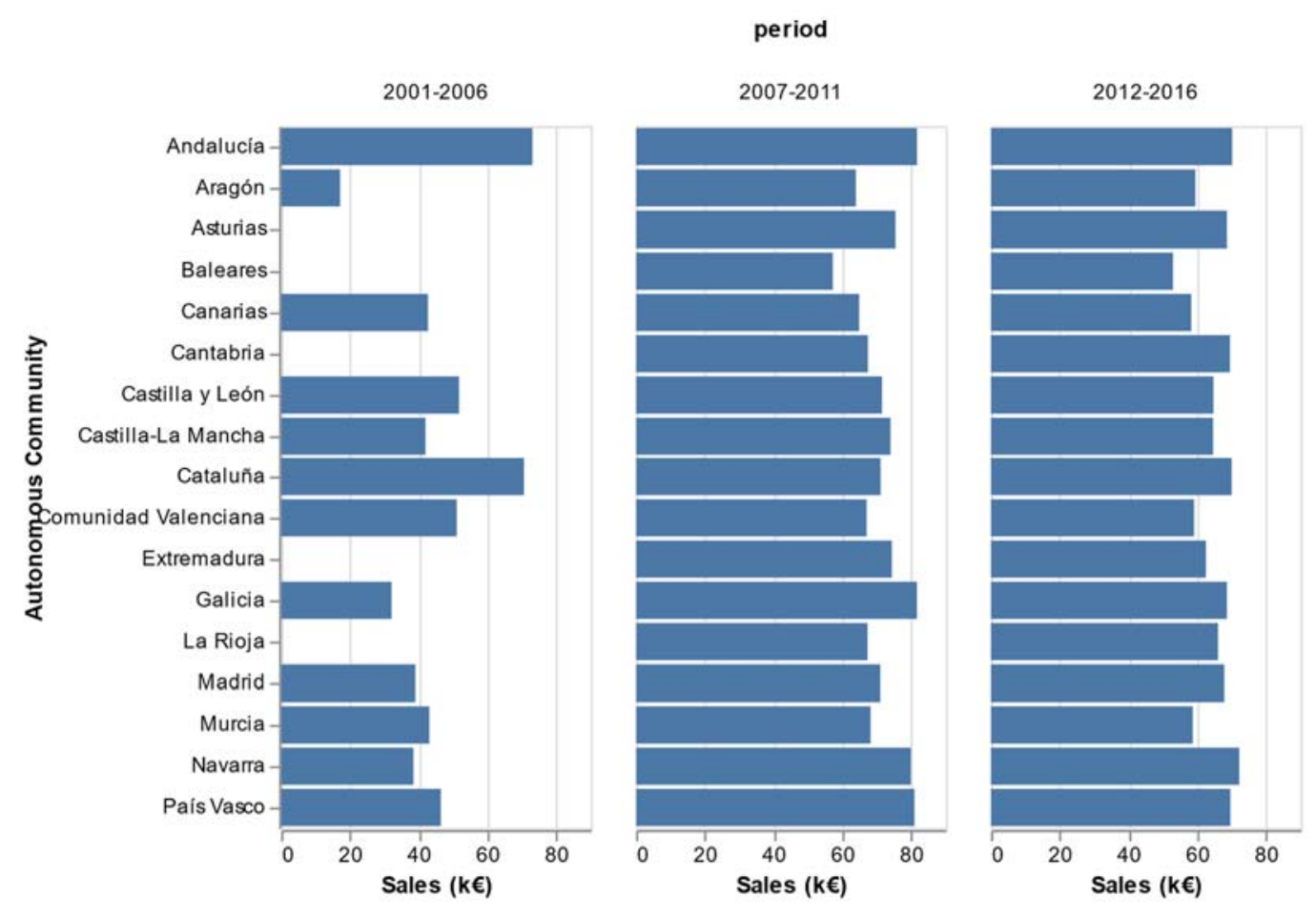

Figure 8. Mean of sales for each Spanish regional government segmented by period.
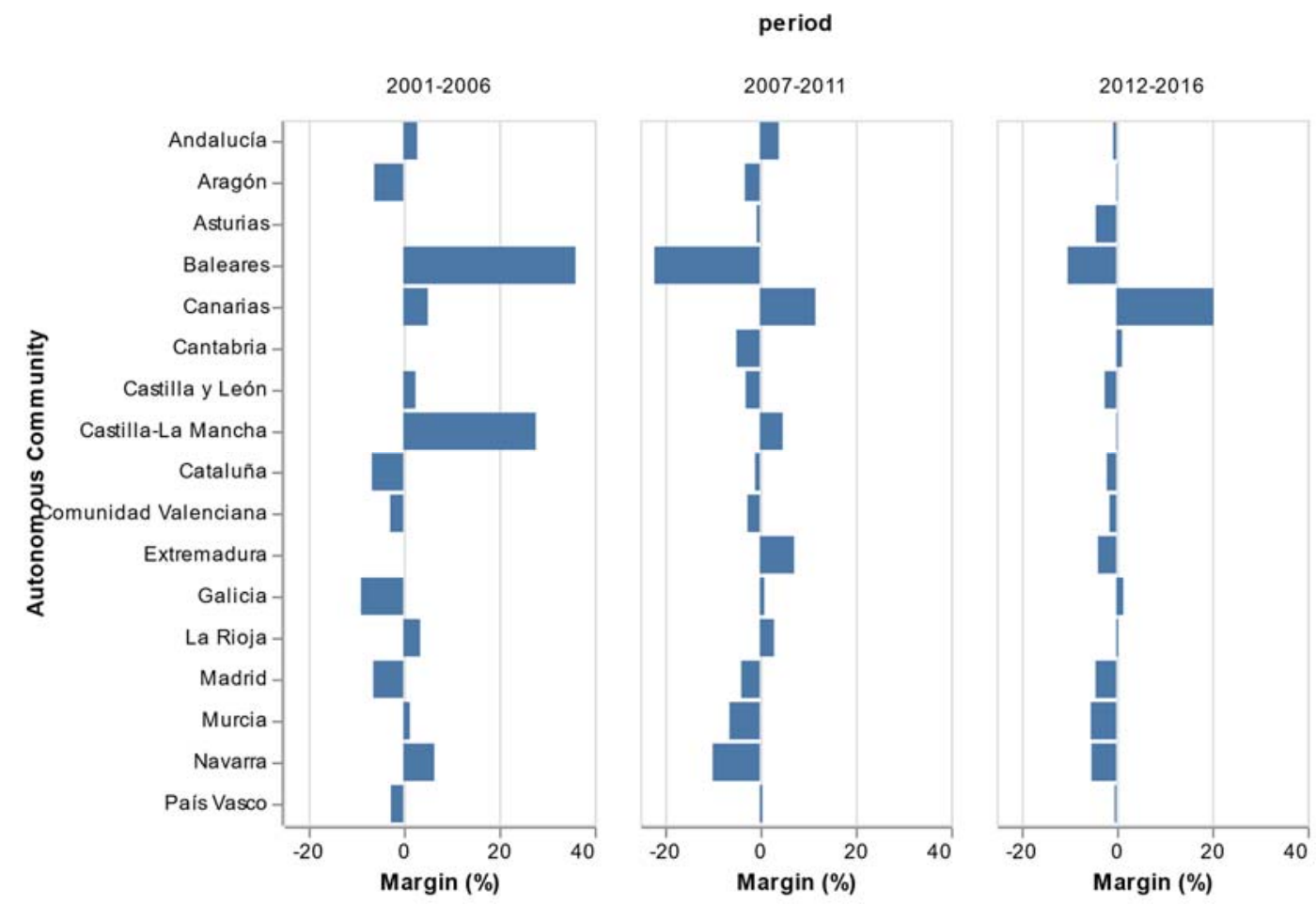

Figure 9. Mean of the operating margin for each Spanish regional government segmented by period.

In terms of financial results, the worst results are focused on the 2007-2011 period (Figure 10). The financial results ratio was calculated taking into account the financial result and the EBIT (Earnings Before Interest and Taxes). Financial expenses in this period increased as the number and amount of 
bank loans granted to the sector grew substantially. As mentioned above, given the high profitability of the policies approved by the executive branch, the Spanish financial system promoted an aggressive investment policy in the solar sector. This strategy attracted a large number of investors-remember that $75 \%$ of them were foreign-and created new products, such as "project finance", to increase the attractiveness of the sector. These loans were financed at an average interest rate of $16 \%$ [19]. In addition to this high level of indebtedness that would begin in 2006, the financial result was affected by the "hold-up" process that took place in 2008, by which investors who had opted for the photovoltaic sector-for having a high profitability and its insured premiums through Law Decrees-found that this situation became reversible, eliminating by law all those subsidies to the sector [14]. When the regulations contained in the decrees law decreased the profitability and the large premiums, the relative increase in the financial result was high. Recall that, following the reductionist trend, the rates approved in Royal Decree 1578/2008 for each subgroup of solar energy decreased in comparison with the Royal Decree of 2004. Facilities with a power equal to or less than $20 \mathrm{~kW}$ are assigned a tariff of $€ 0.32 / \mathrm{kWh}$; while the facilities with a higher power were given a price of $€ 0.34 / \mathrm{kWh}$ (remember that in 2004, most of the installations received a tariff higher than $€ 0.40 / \mathrm{kWh}$ ). That is why in 2009, the creation of new companies decreased and installed photovoltaic capacity stagnated for the first time in four years. Likewise, this process had an impact on the coverage index, which increased two inter-annual points from 2008 to 2009 [19].
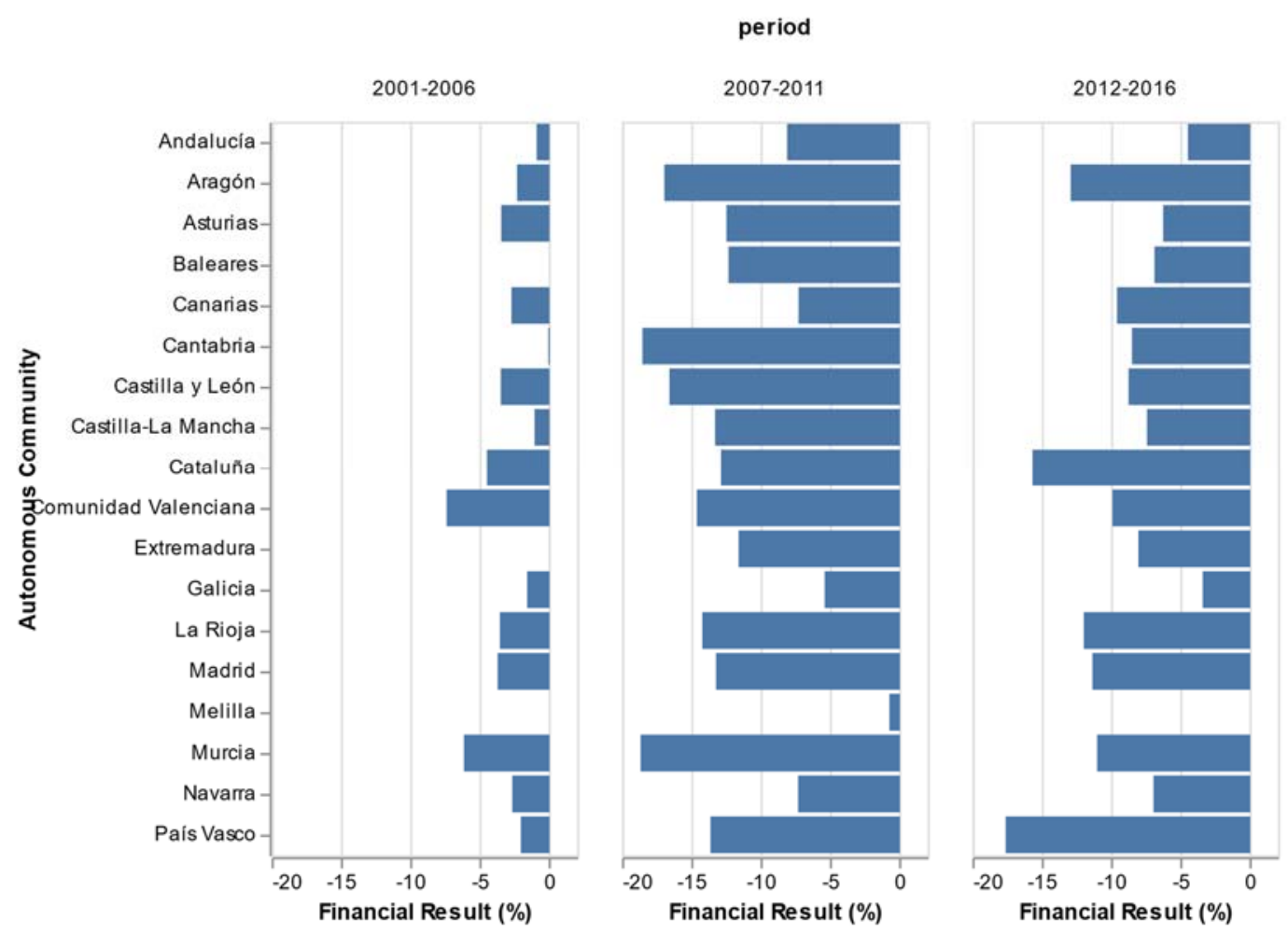

Figure 10. Mean of the Financial Result for each Spanish regional government segmented by period.

In addition, as of 2008, private financing began to suffer, which worsened the aggregate financial result of the sector. The sovereign debt crisis and the euro crisis caused the private financial sector to tighten the conditions for access to credit. This circumstance had a negative effect on the financial results of the companies, which increased their negative trend from 2008 to 2012 [19]. For its part, the Spanish State, faced with this knot in private financing, decided to undertake compensatory measures. However, although a credit line of the Official State Credit Institute was launched in July 2011, with a variable interest rate and a repayment term of seven years maximum, this initiative was not enough to replace the now-defunct private financing [14]. 


\section{Conclusions}

Institutional change is a path that determines the evolution of the rules of the game that establish the incentives of economic agents. The institutional analysis carried out throughout this chapter reflects how the institutional change over the policy of incentives and premiums to the photovoltaic sector explains an expansion phase and a subsequent phase of growth slowdown.

Actually, the legal framework defined by Royal Decree 661/2007, and other subsequent ones, established a system of bonuses and incentives that allowed for the creation of a bubble of the photovoltaic energy sector. It is important to point out that the role of the government was decisive in promoting the Spanish photovoltaic sector, which is interested in betting on energy diversification and renewable energies. In addition to the incentives from the state, there have been other external factors-such as the accessible financing by private banks, the search for a refuge sector to replace the construction sector, or the creation of "project finance"-which promoted the excessive growth of the sector.

However, the high cost of premiums to the sector, in a situation of economic crisis, was the determining factor for the reversal of incentives to the sector. This new situation is an example of a "hold-up" problem, whereby irreversible investments cannot be amortized with a change of political and legal scenario. Proof of the strong slowdown in growth in the sector is the paralysis of the creation of companies in 2012-2016. The establishment of a production quota, the Pre-assignation of Retribution Registry and the progressive reduction of premiums until their disappearance explain this trend. Consequently, the benefits have also been resented. That is why the inter-annual aggregate variations of the benefit variable were negative between 2010 and 2014. The exception is represented by regions such as Andalusia, Canary Islands, or Extremadura where, in addition to being located in an area of high solar radiation, their regional governments have promoted forceful measures to support the sector. On the other hand, the vast majority of Spanish regions have negative benefits.

As we have emphasized above, the institutional constraints have been fundamental. The global crisis of 2008 made the financial conditions harder and, although the state tried to improve this situation with a public credit line, it had, as a consequence, the worsening of the financial results of the companies in the sector. A sector whose indebtedness was not compensated by decreasing $\mathrm{kWh}$ premiums that did not cover the cost of the debt used to finance it.

This case is a good example of the need for a stable institutional framework for the growth and consolidation of a sector. Especially when that sector is an emerging one and is included in a strategic sector such as energy. We have analysed how the economic losses for the sector have been considerable and this situation has led to the closure of companies and the destruction of jobs. However, the consequences are not only noticeable in this sector. The instability and the negative legal change, without compensation, can be perceived by foreign investors as a sign that Spain does not guarantee a stable framework for investment, which can lead to future problems in the country's economy.

Author Contributions: R.F.-G., M.D.-M. and A.S.-G. conceived and designed the analysis, M.Á.Á.F., R.F.-G. and E.A. conducted literature search, A.S.-G., R.F.-G., M.D.-M., E.A. and M.Á.Á.F. contributed to the data analysis and interpretation. All authors participated in the manuscript write up. All authors have read and agreed to the published version of the manuscript.

Funding: Raquel Fernández González gratefully acknowledge the financial support provided by the Xunta de Galicia under Grants ED431C2018/48 and ED431E2018/07 and the Ministry of Economy and Competitiveness under Grant RTI2018-099225-B-100. This research was funded by Regional Government of Castilla y León under the "Support Program for Recognized Research Groups of Public Universities of Castilla y León" (ORDEN EDU/667/2019) and the Spanish Ministry of Science, Innovation \& Universities under the I + D + i state program "Challenges Research Projects" (Ref. RTI2018-098900-B-I00).

Conflicts of Interest: The authors declare no conflict of interest. 


\section{References}

1. Camprubí, L. Whose self-sufficiency? Energy dependency in Spain from 1939. Energy Policy 2019, 125, 227-234. [CrossRef]

2. Bailera, M.; Lisbona, P. Energy storage in Spain: Forecasting electricity excess and assessment of power-to-gas potential up to 2050. Energy 2018, 143, 900-910. [CrossRef]

3. Rodríguez-Rodríguez, D.; Malak, D.; Soukissian, T.; Sánchez-Espinosa, A. Achieving Blue Growth through maritime spatial planning: Offshore wind energy optimization and biodiversity conservation in Spain. Mar. Policy 2016, 73, 8-14. [CrossRef]

4. Energy Supply Security in Southern Europe and Ireland-Science Direct. Available online: https://www. sciencedirect.com/science/article/pii/S1876610217307142 (accessed on 14 January 2020).

5. Gomez, A.; Dopazo, C.; Fueyo, N. The "cost of not doing" energy planning: The Spanish energy bubble. Energy 2016, 101, 434-446. [CrossRef]

6. INEbase/Industria, Energía y Construcción/Industria y Energía. Available online: https://www.ine.es/dyngs/ INEbase/es/categoria.htm?c=Estadistica_P\&cid=1254735576715 (accessed on 14 January 2020).

7. Kumar Sahu, B. A study on global solar PV energy developments and policies with special focus on the top ten solar PV power producing countries. Renew. Sustain. Energy Rev. 2015, 43, 621-634. [CrossRef]

8. Avril, S.; Mansilla, C.; Busson, M.; Lemaire, T. Photovoltaic energy policy: Financial estimation and performance comparison of the public support in five representative countries. Energy Policy 2012, 51, 244-258. [CrossRef]

9. Sánchez-Durán, R.; Barbancho, J.; Luque, J. Solar Energy Production for a Decarbonization Scenario in Spain. Sustainability 2019, 11, 7112. [CrossRef]

10. Escandón, R.; Suárez, R.; Sendra, J.J. Field assessment of thermal comfort conditions and energy performance of social housing: The case of hot summers in the Mediterranean climate. Energy Policy 2019, 128, 377-392. [CrossRef]

11. Green, M.A. Silicon photovoltaic modules: A brief history of the first 50 years. Prog. Photovolt. Res. Appl. 2005, 13, 447-455. [CrossRef]

12. Green, M.A. Short Communication: Price/efficiency correlations for 2004 photovoltaic modules. Prog. Photovolt. Res. Appl. 2005, 13, 85-87. [CrossRef]

13. Meteorología, A.E.; de Atlas de Radiación Solar en España-Agencia Estatal de Meteorología-AEMET. Gobierno de España. Available online: http://www.aemet.es/es/serviciosclimaticos/datosclimatologicos/ atlas_radiacion_solar (accessed on 14 January 2020).

14. Álvarez-Díz, M.; Fernández-González, R.; Caballero, G. Institutional Change, Specific Investments and Photovoltaic Power Plants: The Empirical Effects of the Energy Policy of "Solar Farms" in Spain. In State, Institutions and Democracy: Contributions of Political Economy; Schofield, N., Caballero, G., Eds.; Studies in Political Economy; Springer International Publishing: Cham, Switzerland, 2017; pp. 327-347. ISBN 978-3-319-44582-3.

15. Renewable Energy Statistics. 2019. Available online: https://www.irena.org/publications/2019/Jul/Renewableenergy-statistics-2019 (accessed on 14 January 2020).

16. Spain-Countries \& Regions. Available online: https://www.iea.org/countries/spain (accessed on 14 January 2020).

17. Talavera, D.L.; Muñoz-Cerón, E.; Ferrer-Rodríguez, J.P.; Nofuentes, G. Evolution of the cost and economic profitability of grid-connected PV investments in Spain: Long-term review according to the different regulatory frameworks approved. Renew. Sustain. Energy Rev. 2016, 66, 233-247. [CrossRef]

18. del Río, P.; Mir-Artigues, P. Support for solar PV deployment in Spain: Some policy lessons. Renew. Sustain. Energy Rev. 2012, 16, 5557-5566. [CrossRef]

19. Ibarloza, A.; Heras-Saizarbitoria, I.; Allur, E.; Larrea, A. Regulatory cuts and economic and financial performance of Spanish solar power companies: An empirical review. Renew. Sustain. Energy Rev. 2018, 92, 784-793. [CrossRef]

20. Mir-Artigues, P.; Cerdá, E.; del Río, P. Analysing the economic impact of the new renewable electricity support scheme on solar PV plants in Spain. Energy Policy 2018, 114, 323-331. [CrossRef]

21. Analysing the Impact of Renewable Energy Regulation on Retail Electricity Prices-Science Direct. Available online: https://www.sciencedirect.com/science/article/pii/S0301421517307887 (accessed on 15 January 2020). 
22. Trujillo-Baute, E.; del Río, P.; Mir-Artigues, P. Analysing the impact of renewable energy regulation on retail electricity prices. Energy Policy 2018, 114, 153-164. [CrossRef]

23. Arcos-Vargas, A.; Nuñez, F.; Vivas, J.J. Efficiency improvements in the PV plants market: An application to the Spanish case. Int. J. Energy Sect. Mannag. 2019, 13, 229-254. [CrossRef]

24. Mir-Artigues, P.; Cerdá, E.; del Río, P. Analyzing the impact of cost-containment mechanisms on the profitability of solar PV plants in Spain. Renew. Sustain. Energy Rev. 2015, 46, 166-177. [CrossRef]

25. United Nations Emergency Force. The photovoltaic Sector Is the Driving Force behind the Energy Transition. Annual Report. 2019. Available online: https://unef.es/wp-content/uploads/dlm_uploads/2019/09/memoria_ unef_2019-web.pdf (accessed on 1 February 2020).

26. Report on the Spanish Electricity System 2018|Red Eléctrica de España. Available online: https://www.ree.es/ es/datos/publicaciones/informe-anual-sistema/informe-del-sistema-electrico-espanol-2018 (accessed on 1 February 2020).

27. Study of the Macroeconomic Impact of Renewable Energies in Spain. 2017. Available online: https://www.appa.es/wp-content/uploads/2018/10/Estudio_del_impacto_Macroeconomico_de_las_ energias_renovables_en_Espa\%C3\%B1a_2017.pdf (accessed on 1 February 2020).

28. Asociation Nacional de Productores de Energia Fotovotaica. Anuario Fotovoltaico. 2019. Available online: https://anpier.org/wp-content/uploads/2019/06/anuario245x173-DEF.junio-2019-WEB.pdf (accessed on 17 February 2020).

29. López Prol, J. Regulation, profitability and diffusion of photovoltaic grid-connected systems: A comparative analysis of Germany and Spain. Renew. Sustain. Energy Rev. 2018, 91, 1170-1181. [CrossRef]

30. Mirzania, P.; Ford, A.; Andrews, D.; Ofori, G.; Maidment, G. The impact of policy changes: The opportunities of Community Renewable Energy projects in the UK and the barriers they face. Energy Policy 2019, 129, 1282-1296. [CrossRef]

31. Karteris, M.; Papadopoulos, A.M. Legislative framework for photovoltaics in Greece: A review of the sector's development. Energy Policy 2013, 55, 296-304. [CrossRef]

32. Huijben, J.C.C.M.; Verbong, G.P.J. Breakthrough without subsidies? PV business model experiments in the Netherlands. Energy Policy 2013, 56, 362-370. [CrossRef]

33. North, D.C. Institutions, Institutional Change and Economic Performance Douglass C. North; Cambridge University Press: Cambridge, UK, 1990.

34. Coase, R. The New Institutional Economics. Am. Econ. Rev. 1998, 88, 72-74.

35. North, D.C. The New Institutional Economics. J. Inst. Theor. Econ. 1986, 142, 230-237.

36. Fernández-González, R.; Garza-Gil, M.D.; Pérez-Pérez, M.I. Fundamentos del Análisis Institucional Para La Gestión de Los Recursos Naturales, 1st ed.; Andavira: Santiago de Compostela, Spain, 2018.

37. Williamson, O.E. Reflections on the New Institutional Economics. J. Inst. Theor. Econ. 1985, 141, 187-195.

38. North, D.C. Institutions and Economic Theory. Am. Econ. 2016, 61, 72-76. [CrossRef]

39. Demsetz, H. Toward a Theory of Property Rights. In Classic Papers in Natural Resource Economics; Gopalakrishnan, C., Ed.; Palgrave Macmillan UK: London, UK, 2000; pp. 163-177. ISBN 978-0-230-52321-0.

40. Alston, L.J.; Mueller, B. Property Rights and the State. In Handbook of New Institutional Economics; Ménard, C., Shirley, M.M., Eds.; Springer: Berlin/Heidelberg, Germany, 2008; pp. 573-590. ISBN 978-3-540-69305-5.

41. Miguez, G.C.; Ballesteros, M.A.; Fernández-González, R. La economía política de Elinor Ostrom: Análisis institucional, comunes y gobernanza policéntrica. Rev. Esp. Cienc. Política 2015, 28, 13-40.

42. Williamson, O.E. The New Institutional Economics: Taking Stock, Looking Ahead. J. Econ. Lit. 2000, 38, 595-613. [CrossRef]

43. de la Hoz, J.; Martín, H.; Miret, J.; Castilla, M.; Guzman, R. Evaluating the 2014 retroactive regulatory framework applied to the grid connected PV systems in Spain. Appl. Energy 2016, 170, 329-344. [CrossRef]

44. Joskow, P. Vertical Integration and Long-term Contracts: The Case of Coal-burning Electric Generating Plants. J. Law Econ. Organ. 1985, 1, 33-80.

45. Dixit, A.K. The Making of Economic Policy: A Transaction-Cost Politics Perspective; MIT Press: Cambridge, MA, USA, 1998.

46. Weingast, B.; Marshall, W.J. The Industrial Organization of Congress; or, Why Legislatures, Like Firms, Are Not Organized as Markets. J. Political Econ. 1988, 96, 132-163. [CrossRef] 
47. Socio-Economic and Environmental Effects of Concentrated Solar Power in Spain: A Multiregional Input Output Analysis. Available online: https://dspace.library.uu.nl/handle/1874/343160 (accessed on 15 January 2020).

48. Spiller, P.; Tommasi, M. The Institutional Foundations of Public Policy in Argentina; University Press: Cambridge, UK, 2009.

49. International Energy Agency (IEA). Data and Statistics. Available online: https://www.iea.org/data-andstatistics?country=ITALY\&fuel=Renewables $\% 20$ and $\% 20$ waste\&indicator=Solar $\% 20 \mathrm{PV} \% 20$ electricity $\%$ 20generation (accessed on 1 March 2020).

50. United Nations Emergency Force. Annual Report. 2017. Available online: https://unef.es/wp-content/ uploads/dlm_uploads/2017/07/informe-anual-unef-2017_web.pdf?utm_source=Emailing\&utm_medium= Email\&utm_campaign=Informe+annual+UNEF+2017 (accessed on 20 February 2020).

51. del Rio, P.; Gual, M.A. An integrated assessment of the feed-in tariff system in Spain. Energy Policy 2007, 35, 994-1012. [CrossRef]

52. Mir, P. La regulación fotovoltaica y solar termoeléctrica en España. Cuad. Econ. ICE 2012, 185-205. [CrossRef]

53. Movilla, S.; Miguel, L.J.; Blázquez, L.F. A system dynamics approach for the photovoltaic energy market in Spain. Energy Policy 2013, 60, 142-154. [CrossRef]

(C) 2020 by the authors. Licensee MDPI, Basel, Switzerland. This article is an open access article distributed under the terms and conditions of the Creative Commons Attribution (CC BY) license (http://creativecommons.org/licenses/by/4.0/). 